Full length article

\title{
The performance of banks in the MENA region during the global financial crisis
}

\author{
Guglielmo Maria Caporale ${ }^{\mathrm{a}, *}$, Suman Lodh $^{\mathrm{b}}$, Monomita Nandy

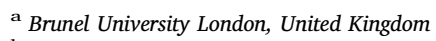 \\ b Middlesex University, United Kingdom
}

\section{A R T I C L E I N F O}

\section{JEL classification:}

G21

\section{Keywords:}

MENA region

Banking sector

Profitability

Global financial crisis

\begin{abstract}
A B S T R A C T
This paper examines the impact of the global financial crisis on the banking sector in the Middle East and North Africa (MENA) region, as well as the main determinants of the profitability of both domestic and foreign banks. The empirical findings suggest that during the crisis the former outperformed the latter in that region. As for the determinants of profitability, size does not appear to play a role, whilst the liquidity ratio and net interest revenues seem to have a negative and positive effect respectively; GDP has a positive effect in the case of domestic banks.
\end{abstract}

\section{Introduction}

The Middle East and North Africa (MENA) region, which includes 28 countries and has a population of 357.3 million, is developing very rapidly and acquiring increasing importance in the global economy. Geographically, it is the bridge connecting Europe and Asia, and it is one of the world's richest regions in terms of resources, since it includes the oil-rich countries of the Gulf Cooperation Council. It is also home to the world's largest Islamic banks, many of which have a global role, serving the Muslim as well as other communities around the world.

Globalisation and the reduction of barriers have allowed foreign banks to enter this region, which has led to greater efficiency and competition (Jeon et al., 2011; Cull et al., 2010; Claessens et al., 2003). Banks benefit from the competitive advantage associated with the new markets they enter (Claessens et al., 2003), but they also contribute to transmitting financial shocks (Claessens and Van Horen, 2011). Financial crises can have different effects on domestic as opposed to foreign banks. For instance, in the case of the 1997-8 Asian crisis the former were affected more than the latter in that region (Detragiache and Gupta, 2006; Jeon and Miller, 2005). However, there is limited evidence concerning the MENA region. The existing papers either focus on individual countries, such as Egypt (Omran, 2007), or consider efficiency and banking performance in the whole region (Olson and Zoubi, 2011) and the possible impact of different types of ownership (Farazi et al., 2011), but none of them analyse the effects of the global financial crisis on the performance of banks in the MENA region as a whole.

The aim of the present study is to fill this gap in the literature by providing evidence on the impact of the crisis on the banking sector, and also identifying the main determinants of profitability of both domestic and foreign banks, in the MENA region. In brief, we find that the former outperformed the latter in this region during the crisis. This result is consistent with the findings of the existing literature on the Asian crisis (Detragiache and Gupta, 2006). Moreover, bank size does not appear to be one of the main factors explaining the profitability of foreign banks, as also found by Athanasoglou et al. (2008) for Greek banks. Finally, GDP affects positively bank profitability (as also reported by Bayraktar and Wang, 2006, and La Porta et al., 2002). Our findings shed light on the

\footnotetext{
* Corresponding author at: Department of Economics and Finance, Brunel University, London UB8 3PH, United Kingdom.

E-mail address: Guglielmo-Maria.Caporale@brunel.ac.uk (G.M. Caporale).
} 
performance of banks in one of the developing regions in the world, and have important policy implications.

The paper is structured as follows: Section 2 provides a brief review of the literature; Section 3 outlines the methodology; Section 4 presents the empirical results; finally, Section 5 offers some concluding remarks.

\section{Literature review}

\subsection{Factors that drive foreign banks to enter a market}

Since our study compares the performance of two types of banks in the region (domestic and foreign), it is useful to consider in the first instance what might motivate a foreign bank to enter another market. Geographical factors clearly matter. For instance, distance is a possible factor (Hryckiewicz and Kowalewski, 2010), or internal management control, with the parent bank possibly losing control over its subsidiary (Berger and Deyoung, 2013), a high level of control normally being seen as crucial to attaining high profitability margins. Further, foreign banks look for locations offering a competitive advantage linked to the familiarity with working conditions in a given climate (Clark et al., 2001). The foreign direct investment (FDI) literature emphasises that in general firms expand abroad to an environment that is very similar to the one in which they are already operating in order to profit from the knowledge advantage from within the firm.

Large banks are more likely to expand abroad than smaller and medium-sized ones: by virtue of their size, they have numerous clients, such as multinational companies, that demand banking services abroad (Clark et al., 2001); in addition, they have a better chance of exploiting the economies of scale associated with expanding abroad. Innovative and efficient banks are also capable of venturing abroad (Clark et al., 2001). Further, empirical studies find evidence of a positive correlation between size and internalisation, and a greater global presence of the world's largest banks (Clark et al., 2001). Grosse and Goldber's (1991) show that the presence of foreign banks in the US is associated with size. Focarelli and Pozzolo (2000) find that bank size affects the pattern of FDI, since large banks have an incentive to follow their clients when they operate abroad.

The characteristics of the host nations in terms of profitability and risk are undoubtedly one of the main factors driving the decision of banks to enter a foreign market (Claessens and Van Horen, 2007). Focarelli and Pozzolo (2000) argue that banks prefer to have subsidiaries in countries where expected profits are larger, as a result of higher expected economic growth, as well as being able to take advantage of the inefficiencies of local banks. Further, the penetration of foreign banks is significantly higher in the case of countries that have similar legal systems and banking and regulatory set-ups, probably because the operating costs and risks are lower in such countries (Claessens and Van Horen, 2007). But whether these factors are equally important for foreign banks, particularly during financial crises and in the case of the MENA region, is yet to be examined.

\subsection{Impact of foreign banks' entry on the host nation}

The impact of foreign banks entering developing markets has long been debated by academics and policy makers: on the one hand, they could bring in much-needed capital, technical skills and product innovation, and greater competition to the banking sector of developing economies; on the other hand, there might also be adverse, destabilising effects for the host nations from the transmission of financial shocks (Cull et al., 2010).

Large information barriers discourage the entry of foreign banks (Buch, 2003), whilst different modes of entry affect the degree of competition in various ways (Van Tassel and Vishwasrao, 2007). For example, the Greenfield mode of entry could lead to lower interest rates in the host country, with advantages for clients. But greater competition does not always have positive results. Boot and Marinc (2013), for example, argue that increasing the number of players in the market to create more competition may reduce banks' incentives to invest in better monitoring technologies. High competition can generate a non-efficient credit allocation system (Schnitzer, 2013), which increases the probability of bad loans in the economy and can lead to a decline in the quality of the banks' loan portfolio (Broecker, 1990). Other researchers argue that a higher percentage of foreign banks leads to higher efficiency in the host nation (Fries and Taci, 2005). Claessens and Lee (2003) find that the entry of foreign banks lowers net interest margins, profitability, cost ratios, and non-interest income for domestic banks in developing countries. Fewer restrictions on banks' activities can generate greater competitiveness in the host nations (Cull et al., 2010). Most researchers believe that there is a positive link between foreign bank penetration and competition as well as economic growth and the efficiency of resource allocation (Jeon et al., 2011).

There is evidence that during the Asian and the recent global financial crisis foreign banks have been an important transmission channel of risk from one country or region to another. In the case of the MENA region there are various channels (financial markets, oil market, tourism, global asset market etc. - Assaf, 2016) which can result in higher stock market volatility. However, a comparison between the role of domestic and foreign banks has not been made yet.

\subsection{The entry mode of foreign banks}

FDI inflows into the least developed countries account for about 1.7\% of global FDI, i.e. almost double their share of world GDP. In 2001-2010 FDI increased, as did other private capital inflows and dual aid inflows also increased. In 2006-2009 FDI averaged $6.3 \%$ of GDP (compared to $2.6 \%$ in the developed economies, $4.6 \%$ in the transition economies, $3.6 \%$ in the developing economies, and $2.9 \%$ for the world economy as a whole - Davies, 2011). FDI is one of the main entry methods of foreign banks, especially in developing economies: this rose sharply from 11\% in 1995-65\% in 2003 for Eastern Europe (Claeys and Hainz, 2006), and at a slower 
pace for other regions such as Latin America, Asia, Africa and the Middle East (Clarke et al., 2001), usually being in the form of branches and subsidiaries, as a result of financial liberalisation policies removing barriers to entry.

The Arab countries in the MENA region started to amend their financial sectors only in the 1990s, relatively late compared to those in Latin America and Asia. Many of them, such as Algeria, Libya and Syria, still have state-dominated, as well as inappropriately regulated, financial systems (Lee, 2002). The World Trade Organisation (WTO) agreements on financial services of 1995 and 1997 hastened the privatisation and divestiture of state-owned firms, the restructuring of domestic firms and the removal of excessive regulations to open up domestic financial markets to foreign bank entry (Hassan et al., 2012). Interest rate spreads (lending rates minus deposit rates) have declined in the MENA countries as a result of liberalisation and the increase in competition brought about by the entry of foreign banks (Lee, 2002).

\subsection{Bank ownership and performance}

There is an ongoing debate in the literature on the effects of ownership on bank performance. Foreign banks can provide higher interest rate margins and generate high profit by incurring low costs in developing economies in comparison to domestic banks (Demnirguci-Kunt and Huizinga, 2000; Micco et al., 2007). La Porta et al. (2002) argue that wider state ownership of banks is one of the reasons for slower economic growth and financial development in developing economies. Foreign ownership generally leads to better performance than domestic (state) ownership in developing countries, in contrast to the developed countries, where domestic banks tend to outperform foreign banks (see Berger et al., 2000 for the UK, France and Germany; Sturm and Williams, 2004 for Australia). The existing studies on the MENA region only consider the period before the financial crisis and focus on individual countries (Olson and Zoubi, 2011; Farazi et al., 2011; Lassoueda et al., 2016), but, since the protection of shareholders' right is very weak in that region, it is important to study the ownership structure in detail (Ayadi et al., 2011).

\subsection{Financial crisis and banking performance}

Previous studies suggest that foreign banks restricted their lending in 2008-09 more than domestic ones and arguably contributed to financial instability (Claessens and Van Horen, 2011). There is also evidence of less credit by domestic banks during the crisis and steady credit by foreign banks that followed the Greenfield entry mode (De Haas and Van Lelyveld, 2006). For example, in the Asian region Malaysia has seen a rapid influx of foreign banks, specifically subsidiaries of Asian banks (Hong Kong S.A.R, Japan, Singapore, Thailand), as well as of UK, North American and European banks (Detragiache and Gupta, 2006).

Very few studies consider the effects of financial crises on the performance of banks in developing economies. Jeon and Miller (2005) examine them in Korea before and after the Asian financial crisis and find that on average foreign banks outperformed domestic ones (who received state aid in 1998-99) because of their global advantage and lower exposure to risk. The MENA region has the highest percentage of Islamic banks in the world, which might have alleviated the effects of the crisis (Parashar and Venkatesh, 2010). It is important to examine the performance of domestic and foreign banks separately especially in an emerging region such as MENA, where most of the financial assets are controlled by banks.

\subsection{Determinants of bank profitability}

The existing literature considers both internal and external determinants of bank profitability. In general, it finds evidence of variations in asset and equity returns depending on size, liquidity, capital strength, net interest margin, or net interest revenues, mainly for the developed markets (Van Horen, 2007; Micco et al., 2007). In most studies size is considered to be one of the most important determinants of bank performance (for both Islamic and conventional banks) (Athanasoglou et al., 2008) A large size generates economies of scale and gives access to markets that smaller banks cannot enter (Heggestad, 1997). The need for risk management is intrinsic to the nature of the banking business. Bad asset quality and low levels of liquidity are the two major causes of bank failures (Nandy and Lodh, 2012). During periods of increased uncertainty, financial institutions may decide to diversify their portfolios and/or raise their liquid holdings in order to reduce their credit or liquidity risk. Bourke (1989) find a positive and strong association between liquidity and banks' profitability. Recent studies show that loans are linked to profitability and performance (see Staikouras et al., 2008), and that investment decisions can affect profitability adversely (Valverde and Fernández, 2007). Capital strength (the equity to asset ratio) can also be used to predict the performance of banks. Berger (1995) finds that it is positively linked to profitability in the case of US banks. The Basel committee on the banking sector set some minimum requirements to enable banks to absorb any shocks they might face (Kosmidou et al., 2007).

The external determinants of profitability are macroeconomic variables such as the inflation rate, GDP, and the money supply growth rate. Existing studies provide evidence of a positive impact of GDP on bank performance in developed markets (Demriguc et al., 2000; Athanasoglou et al., 2008). There is also evidence that foreign banks improve efficiency and competitiveness of domestic banks, which enhances economic growth (see, e.g., Bayraktar and Wang, 2006).

\section{Data and methodology}

To investigate the impact of the crisis upon domestic and foreign banks in the MENA region, following Ralph and Iman, we collect information on bank internal characteristics from the Bankscope database. We use the Bankscope ownership identifier, which considers a bank as foreign owned if it has a branch or a subsidiary in a different country. The macroeconomic variables are obtained 
Table 1

Definition of variables used.

Dependent variables—measures of bank performance

1. $\log$ ROAA $=\log$ of return on average assets

Bank internal characteristics

Independent variables

3. Log of lag SIZE $=\log$ of lag (total assets).

4. Log LOANS $=\log ($ Net loans) $=\log$ (total net loans/total assets).

External variables

5. Log INFL = Logarithm of annual country inflation rate in percentage.

6. GDP $=$ Gross domestic product.

7. Ownership = dummy variable equal to one if the bank is foreign, zero if domestic bank.

8. Crisis = dummy variable equal to one if years are between 2008-2010, zero if years are between 2000 and 2007.

from the World Bank database. The definition of the variables are given in Table 1.

Our dataset includes both foreign and domestic banks in the MENA region during the period 2000-2012. The original dataset covered 515 different banks from 24 MENA countries. However, we have excluded some countries, due to the unavailability of data on some variables. The final dataset consists of 76 foreign and 46 domestic banks from the 17 MENA countries listed in Table 2.

When assessing the performance of banks most of the literature uses two accounting measures: the return on assets, defined as net income divided by total assets (ROA), or the return on equity (ROE), calculated as net income returned as a percentage of shareholders' equity (Van Horen, 2007). In this study both return on average assets (ROAA) and return on average equity (ROAE) are considered.

The determinants of banks' performance are classified in four categories. The first is ROAA, since Pasiouras et al. show that this is indeed a key measure of bank profitability. The second includes banks' internal characteristics, specifically total assets, liquidity, and net interest revenues. Total assets are used to capture the relationship between bank size and profitability (Kosmidou et al., 2007). The liquidity ratio is the ratio of loans to total assets. Staikouras et al. (2008) show that loans are positively linked to profitability measures. However, if banks issue loans very generously that will have a negative impact on profitability. Interestingly, choosing different control variables can make the impact on profitability positive (Valverde and Fernández, 2007). Net interest revenue is the difference between the revenues generated from a bank's assets and the expenses associated with paying out its liabilities. The existing literature on the determinants of Islamic banks' profitability in the MENA region shows that the net interest revenue is a significant determinant of profitability (e.g. Ben Khediri and Ben-Khedhiri, 2009).

The third set includes the macroeconomic variables, namely annual GDP per capital growth, and the annual inflation rate. There is not much empirical evidence on the direct links between the banking sector, openness and economic growth - most of it concerns indirect links, and suggests that foreign banks play a significant role in enhancing and improving the efficiency and competitiveness of domestic banks (Bayraktar and Wang, 2006). The last set of variables includes the ownership identifier and the crisis variable. The former distinguishes between foreign banks in the MENA region and domestic banks. The latter, on the other hand, refers to the 2008-2010 crisis period (variable definitions are shown in Table 1).

Table 2

Total number of foreign and domestic banks within the 17 MENA countries.

\begin{tabular}{|c|c|c|c|}
\hline Country & Number of foreign banks & Number of domestic banks & Total number of banks \\
\hline Israel & 5 & 4 & 9 \\
\hline Saudi Arabia & 11 & 3 & 14 \\
\hline UAE & 8 & 9 & 17 \\
\hline Egypt & 9 & 6 & 15 \\
\hline Lebanon & 9 & 3 & 12 \\
\hline Kuwait & 5 & 4 & 9 \\
\hline Bahrain & 6 & 3 & 9 \\
\hline Iran & 3 & 2 & 5 \\
\hline Jordan & 6 & 0 & 6 \\
\hline Qatar & 1 & 3 & 4 \\
\hline Oman & 2 & 3 & 5 \\
\hline Algeria & 3 & 1 & 4 \\
\hline Morocco & 1 & 2 & 3 \\
\hline Libya & 0 & 3 & 3 \\
\hline Tunisia & 5 & 0 & 5 \\
\hline \multirow[t]{2}{*}{ Yemen } & 2 & 0 & 2 \\
\hline & Foreign banks $=76$ & Domestic banks $=46$ & Total banks $=122$ \\
\hline
\end{tabular}


Table 3a

Descriptive statistics of all variables (ROAA, ROAE, total assets, net loans, net interest revenues, GDP, inflation) for the period $2000-2012$.

\begin{tabular}{|c|c|c|c|c|c|c|c|}
\hline \multicolumn{8}{|c|}{ Descriptive statistics } \\
\hline & ROAA & ROAE & Total assets & Net loans & Net interest revenues & GDP & Inflation \\
\hline Mean & 1.608233 & 12.17624 & 11518231 & 48.87479 & 245755.9 & 4.940032 & 6.938747 \\
\hline Median & 1.357 & 11.6075 & 4990798 & 52.182 & 94389.51 & 4.700005 & 6.048306 \\
\hline Maximum & 35.102 & 107.269 & 95748235 & 96.857 & 2158846 & 20.84316 & 28.28166 \\
\hline Minimum & -17.823 & -135.994 & 54730.3 & 0 & -1832962 & -10.4797 & -24.2494 \\
\hline Std. Dev. & 2.300377 & 14.18022 & 15309365 & 22.03983 & 373513.8 & 3.563588 & 8.806041 \\
\hline Observations & 1104 & 1104 & 1104 & 1104 & 1104 & 1104 & 1104 \\
\hline
\end{tabular}

\subsection{Model}

Micco et al. (2007) and others use the return on average assets (ROAA) to measure banking profitability, which is the dependent variable in our model, specified as follows:

$$
\begin{aligned}
Y_{i t}= & \alpha_{i t}+\beta_{1} \text { Crisis }_{i t}+\beta_{2} \log (\text { Total Assets })_{i(t-1)}+\beta_{3} \log \left(\text { Net } \text { Loans }_{i t}+\beta_{4} \log (\text { Net Interest Revenue })_{i t}+\beta_{5} \text { Ownership }_{i t}\right. \\
& +\beta_{6} \log (\text { GDP })_{i t}+\beta_{7} \log (\text { Inflation })_{i t}+\varepsilon_{i t}
\end{aligned}
$$

where $Y_{i t}$ is ROAA, $\alpha_{i t}$ is the intercept, $\beta_{i t}$ is the regression coefficient on the i explanatory variable, and $\varepsilon_{i t}$ is the error term assumed to be normally distributed with mean zero. This is a log-log multivariate model. Two additional models are also estimated to assess the impact of the crisis on each of the two categories of banks. Finally, two random effects models are also considered, where the error term is adjusted for each individual bank. A Hausman test is carried out to ensure that the random effects are appropriate for our panel. The estimation method is OLS.

\subsection{Descriptive statistics}

Table 3a shows descriptive statistics for all series (internal bank characteristics and macroeconomic variables) for both domestic and foreign banks operating in the MENA countries during the period 2000-2012. The variables appear to be normally distributed. Average profitability, as measured by ROAA and ROAE, equals $1.6 \%$ and $12.17 \%$ respectively. It can be seen that banks in the MENA region perform relatively poorly Compared to those in developed countries, as also shown by other studies (Farazi et al., 2011; Micco et al., 2007). The median of ROAA and ROAE equals 1.357 and 11.61 respectively, and the standard deviation 2.3 and 14.18.

Table 3b shows that the degree of skewness of the variables is much lower when logs are taken. For instance, the dependent variable Log ROAA has a mean value of 0.224576 and a median of 0.396761 , and maximum and minimum values of 3.558258 and -4.96185 respectively. Log total assets has a mean value of 25.15 and a median of 25.35 , and its maximum and minimum values are 15.57 and 18.37 respectively.

\section{Empirical results}

\subsection{Correlation matrix}

Table 4 shows the correlations. The variables are divided in three groups: all banks, foreign banks from the MENA region, and domestic banks.

ROAA and ROAE are negatively correlated to each other. Moreover, total assets and net loans are inversely related to both ROAA and ROAE in all cases. Net interest revenue has a weak correlation with ROAA and ROAE. The macroeconomic variables (GDP, inflation) have a small and positive correlation with ROAA and ROAE except for the correlation between GDP and ROAE.

Table $3 \mathbf{b}$

Descriptive statistics of all logarithmic variables (log ROAA, log ROAE, log total assets, log net loans, log net interest revenues, log GDP, log inflation) for the period

\begin{tabular}{|c|c|c|c|c|c|c|c|}
\hline \multicolumn{8}{|c|}{ Descriptive statistics (log variables) } \\
\hline & ROAA & ROAE & Total assets & Net loans & Net interest revenues & GDP & Inflation \\
\hline Mean & 0.225 & 2.345 & 15.460 & 3.696 & 11.649 & 1.539 & 1.815 \\
\hline Median & 0.397 & 2.515 & 15.571 & 3.987 & 11.676 & 1.589 & 2.140 \\
\hline Maximum & 3.558 & 4.675 & 18.377 & 4.573 & 14.585 & 3.037 & 3.342 \\
\hline Minimum & -4.962 & -3.147 & 11.167 & -5.809 & 4.605 & -2.055 & -2.808 \\
\hline Std. Dev. & 1.020 & 0.868 & 1.445 & 1.052 & 1.506 & 0.713 & 1.109 \\
\hline Observations & 803 & 803 & 803 & 803 & 803 & 803 & 803 \\
\hline
\end{tabular}
2000-2012. 
Table 4

Correlation results of both domestic MENA banks, and foreign banks from MENA.

\begin{tabular}{|c|c|c|c|c|c|c|c|}
\hline & 1 & 2 & 3 & 4 & 5 & 6 & 7 \\
\hline 1.ROAA & 1.000 & & & & & & \\
\hline 2. ROAE & -0.029 & 1.000 & & & & & \\
\hline 3. Total assets & -0.138 & 0.057 & 1.000 & & & & \\
\hline 4. Net loans & -0.024 & -0.003 & 0.100 & 1.000 & & & \\
\hline 5. Net interest revenues & 0.003 & 0.091 & 0.873 & 0.192 & 1.000 & & \\
\hline 6. GDP & 0.039 & -0.092 & -0.026 & -0.072 & -0.030 & 1.000 & \\
\hline 7. Inflation & 0.115 & 0.016 & 0.083 & -0.001 & 0.082 & 0.118 & 1.000 \\
\hline
\end{tabular}

\subsection{Regression results}

Eq. (1) is estimated to assess the impact of the crisis on domestic banks and foreign banks from the MENA region jointly (Model 1) and separately (Model 2 and 3); the results are reported in Table 5. All the internal bank characteristics, as well as the macroeconomic variables, are statistically significant at the 5\% level in Model 1.

The coefficient on total assets, which reflects bank size, is negative and significant. The high percentage of Islamic banks within the MENA region is presumably the main reason for this finding. The liquidity ratio also appears to have a significant and negative impact on banks' profitability in this region. Other studies point out that the sign of this effect depends on whether or not at times of uncertainty banks decide to diversify their portfolios, which leads to an increase in their liquidity holding to compensate for their risk, and hence lower returns (Staikouras et al., 2008; Kosmidou et al., 2007). Net interest revenues have a significant and positive effect on profitability, consistently with other studies (Ben Khediri and Ben-Khedhiri, 2009).

The estimated coefficient on GDP is positive for the full sample, as also found by other studies on the impact of foreign banks' entry into developing and emerging markets (e.g., Jeon et al., 2011): this tends to improve the efficiency of domestic players in the market, and promotes economic growth by boosting the efficiency of resource allocation. In addition, Bayraktar and Wang (2006) find that foreign banks enhance economic growth by improving competition of other players in the financial markets. Athanasoglou et al. (2006) also find a positive association between GDP growth and profitability.

Next we discuss the estimation results for the two models analysing the impact of the crisis upon domestic and foreign banks separately.

\section{Domestic banks}

$$
\begin{aligned}
\log (\text { ROAAD })_{i t}= & \alpha_{i t}+\beta_{1} \text { Crisis }_{i t}+\beta_{2} \log (\text { Total Assets } D)_{i(t-1)}+\beta_{3} \log (\text { Net Loans } D)_{i t}+\beta_{4} \log (\text { Net Interest RevenueD })_{i t} \\
& +\beta_{5} \log (G D P)_{i t}+\beta_{6} \log (\text { Inflation })_{i t}+\varepsilon_{i t}
\end{aligned}
$$

The above model is use to test the impact of the crisis on domestic (_D) banks only (see the results for Model 2 in Table 5). The crisis coefficient $\left(\beta_{1}=-0.136\right)$ is negative and statistically insignificant. The explanation might be that the MENA region is home to the world's largest Islamic banks: these appear to have had a comparative advantage over conventional banks and to have outperformed them during and after the crisis (Bourkhisa and Sami Nab, 2013).

\section{Foreign banks}

$$
\begin{aligned}
\log (R O A A F)_{i t}= & \alpha_{i t}+\beta_{1} \text { Crisis }_{i t}+\beta_{2} \log (\text { Total Assets } F)_{i(t-1)}+\beta_{3} \log (\text { Net Loans } F)_{i t}+\beta_{4} \log (\text { Net Interest RevenueF })_{i t} \\
& +\beta_{5} \log (G D P)_{i t}+\beta_{6} \log (\text { Inflation })_{i t}+\varepsilon_{i t}
\end{aligned}
$$

The above model is use to test the impact of the crisis on the foreign (_F) banks only (see the results for Model 3 in Table 5). The F test

Table 5

Regression results of least square estimation.

\begin{tabular}{lll}
\hline Dependent Variable: ROAA & $\begin{array}{l}\text { Full Sample } \\
\text { Model 1 }\end{array}$ & $\begin{array}{l}\text { Domestic Bank } \\
\text { Model 2 }\end{array}$ \\
\hline Crisis & $-0.191(0.078)^{*}$ & $-0.136(0.118)$ \\
Log (total assets) (t-1) & $-0.491(0.045)^{*}$ & $-0.274(0.070)^{*}$ \\
Log (net loans) & $-0.085(0.033)^{*}$ & $-0.089(0.079)$ \\
Log (net interest revenues) & $0.407(0.044)^{* *}$ & $0.150(0.076)^{*}$ \\
GDP & $0.018(0.010)^{*}$ & $0.042(0.013)^{*}$ \\
Log (inflation) & $-0.127(0.031)^{*}$ & $0.138(0.045)^{*}$ \\
Observations & 803 & 803 \\
Intercept & $3.082(0.391)^{*}$ & $2.606(0.605)^{*}$ \\
Adjusted R square & 0.149 & 0.144 \\
F-statistic & 21.8 & $0.103(0.059)^{*}$ \\
\end{tabular}

Notes: Standard errors are in parentheses. ${ }^{*} \mathrm{p}<0.05,{ }^{* *} \mathrm{p}<0.01$. Model 1,2 and 3 are showing all coefficients of full sample, domestic banks and foreign banks respectively. 
Table 6

Regression results of random effect estimation.

\begin{tabular}{lll}
\hline Dependent Variable: ROAA & $\begin{array}{l}\text { Domestic } \\
\text { Model 4 }\end{array}$ & $\begin{array}{l}\text { Foreign } \\
\text { Model } 5\end{array}$ \\
\hline Crisis & $-0.105(0.016)^{*}$ & $-0.272(0.103)^{*}$ \\
Log (total assets) (t-1) & $-0.277(0.067)^{*}$ & $-0.620(0.060)^{*}$ \\
Log (net loans) & $-0.081(0.076)^{*}$ & $-0.103(0.038)^{*}$ \\
Log (net interest revenues) & $0.147(0.073)$ & $0.520(0.056)^{*}$ \\
GDP & $0.038(0.012)^{*}$ & $-0.009(0.017)$ \\
Log (inflation) & $0.079(0.043)^{* *}$ & $0.111(0.046)^{*}$ \\
Observations & 562 & 562 \\
Intercept & $2.716(0.578)^{*}$ & $3.924(0.527)^{*}$ \\
Adjusted R square & 0.180 & 0.170 \\
F-statistic & 15.4 & 23.23 \\
\hline
\end{tabular}

Notes: Standard errors are in parentheses. ${ }^{*} \mathrm{p}<0.05$, ${ }^{* *} \mathrm{p}<0.01$. Model 4 and 5 are showing all coefficients of domestic banks and foreign banks respectively.

confirms the joint significance of the regressors. The crisis coefficient $\left(\beta_{1}=-0.187\right)$ is negative and statistically significant at the $10 \%$ level. The measured impact is bigger than in the case of the domestic banks: foreign banks from the MENA region may have more subsidiaries in developed countries and therefore have been more affected by the global crisis.

\subsection{Comparative analysis of domestic and foreign banks in the MENA}

As mentioned above, pooled OLS cannot control for firm-specific unobserved heterogeneity. The Hausman test (including its Wooldridge version) suggests that the firm-specific characteristics are associated with the error term and therefore a random (rather than fixed) effect model should be estimated.

The regression results shown in Table 6 indicate that in the case of domestic banks most internal bank characteristics are statistically significant (at the 1\% level), with the only exception of the log of net loans. As for the macroeconomic variable, GDP and log inflation are statistically significant at the $5 \%$ and $10 \%$ level respectively. Similar results are obtained for the foreign banks, the main difference being that GDP is now statistically insignificant.

The estimated coefficient on the dummy variable confirms that foreign banks were more affected than domestic ones by the crisis (see Model 4 in Table 6): their profits (ROOA) decreased by $27.2 \%$ as opposed to $10.5 \%$ in the case of the latter, reflecting their higher degree of exposure to risk given the fact that they have subsidiaries in developed countries (see also Bertrand et al., 2005).

As for the role of internal bank characteristics, the coefficient on total assets is negative and significant. This might be the result of managerial inefficiency when banks become larger (Kosmidou et al., 2007). The coefficient on the liquidity ratio (net loans) is negative and statistically significant for foreign banks. This is in line with the findings of other studies (Staikouras et al., 2008; Kosmidou et al., 2007). Finally, the coefficient on net interest revenues is positive for both models.

Finally, the coefficient on GDP is positive and significant for domestic banks, whilst no effect is found in the case of foreign banks. Clearly, banks are affected by the economic environment in which they operate (De Haas and Van Lelyveld, 2006).

\section{Conclusions}

The aim of this paper is to investigate the effects of the global financial crisis on the performance of both domestic and foreign banks in the MENA region, and also to identify the main determinants of their profitability. It provides comprehensive evidence for the MENA region which is of interest also to policy makers and practitioners. The main finding is that domestic banks outperformed foreign banks during the crisis. This reflects the fact that they include the world's largest Islamic banks, who appear to have had a comparative advantage and to have been less affected by the crisis (Bourkhisa and Sami Nab, 2013). Foreign banks had a higher degree of exposure to risk given their higher number of subsidiaries in the developed economies.

As for the determinants of profitability, size does not appear to play a role (as also found by studies focusing on other countries see, e.g., Athanasoglou et al., 2008). The liquidity ratio seems to have a negative effect, presumably because higher uncertainty leads to higher liquidity holdings and lower returns (Staikouras et al., 2008; Kosmidou et al., 2007). Net interest revenue has a positive effect (see also Ben Khediri and Ben-Khedhiri, 2009), and so does GDP in the case of domestic banks.

\section{References}

Assaf, A., 2016. MENA stock market volatility persistence: evidence before and after the financial crisis of 2008. Res. Int. Bus. Finance 36, 222-240. Athanasoglou, P., Brissimis, S., Delis, M., 2008. Bank-specific, industry-specific and macroeconomic determinants of bank profitability. J. Int. Financ. Mark. Inst. Money 18 (2), 121-136.

Bayraktar, N., Wang, Y., 2006. Banking Sector Openness and Economic Growth. World Bankpp. 1-22. http://elibrary.worldbank.org/docserver/download/4019.pdf? expires $=1377540056 \&$ id $=$ id\&accname $=$ guest\&checksum $=$ B130EC73181999092071D9F8A62C13FE [Accessed: 26, August 2013].

Ben Khediri, K., Ben-Khedhiri, H., 2009. Determinants of Islamic bank profitability in the MENA region. Int. J. Monet. Econ. Finance 2 (3/4), 409-416. Berger, A., Deyoung, R., 2013. The effects of geographic expansion on bank efficiency. J. Financ. Serv. Res. 19, $163-184$. 
Berger, A., Deyoung, R., Genay, H. and F. Udell, G., 2000. Globalization of Financial Institutions: Evidence from Cross-Border Banking Performance. BrookingsWharton Papers on Financial Services. http://muse.jhu.edu/journals/pfs/summary/v2000/2000.1berger.html [Accessed: 20, July 2013].

Berger, A., 1995. The profit-structure relationship in banking-tests of market-power and efficient-structure hypotheses. J. Money Credit Bank. 27 (2), 404-420.

Bertrand, M., Schoar, A., Thesmar, D., 2005. Banking Deregulation and Industry Structure: Evidence from the French Banking Reforms of 1985 . University of Chicago Graduate School of Business, Chicago, pp. 2-26. Available through: dev3. cepr.org http://dev3.cepr.org/meets/wkcn/6/6625/papers/Thesmar.pdf [Accessed: 09, August 2013].

Boot, A., Marinc, M., 2013. Competition and Entry in Banking: Implications for Stability and Capital Regulation. Tinbergen Institute, and CEPR, Amsterdam. p. 24. Available through: http://www.tinbergen.nl./ http://papers.tinbergen.nl/06015.pdf [Accessed: 13, July 2013].

Bourke, P., 1989. Concentration and other determinants of bank profitability in Europe, North America and Australia. J. Bank. Finance 13 (1), 65-79.

Bourkhisa, K., Sami Nab, M., 2013. Islamic and conventional banks' soundness during the 2007-2008 financial crisis. Rev. Financ. Econ. 22 (2), 68-77.

Broecker, T., 1990. Credit-worthiness tests and interbank competition. Econometrica 58 (2), 429-452.

Buch, C.M., 2003. Information or regulation: what drives the international activities of commercial banks? J. Money Credit Bank. 35 (6), $851-869$.

Claessens, S., Lee, J., 2003. Foreign Banks in Low-Income Countries: Recent Developments and Impacts 1. World Bank, Amsterdam, pp. 2-11. http://www1. fee.uva. $\mathrm{nl} / \mathrm{fm} /$ PAPERS/Claessens/Foreign\%20Banks.pdf [Accessed: 26, April 2013].

Claessens, S., Van Horen, N., 2007. Decisions of Foreign Banks and Competitive Advantage. World Bankpp. 1-13. Available through: http://econ.worldbank.org . http://elibrary.worldbank.org/docserver/download/4113. pdf?expires =1377537071\&id=id\&accname=guest\&checksum $=$ A88FB5D737726D9B51BF7783A1108C5E [Accessed: 26, March 2013].

Claessens, S. and Van Horen, N. 2011. Foreign Banks: Trends, Impact and Financial Stability. Amsterdam: DNB Working paper No.330. pp. 2-23.

Cull, R., Soledad, M., Peria, M., 2010. Foreign Bank Participation in Developing Countries. World Bankpp. 2-17. Available through: World Bank http://elibrary. worldbank.org/docserver/download/5398. pdf?expires =1377536606\&id =id\&accname = guest\&checksum = 8E27B8CCD286A39030F8EFDC56A2C491 [Accessed: 26, March 2013].

De Haas, R., Van Lelyveld, I., 2006. Foreign banks and credit stability in Central and Eastern Europe. A panel data analysis. J. Bank. Finance 30 (7), $1927-1952$.

Demnirguci-Kunt, A., Huizinga, H., 2000. Determinants of Commercial Bank Interest Margins and Profitability. World Bankpp. 2-17. http://www-wds.worldbank.org/ servlet/WDSContentServer/WDSP/IB/1998/03/01/000009265_3980429111510/Rendered/PDF/multi_page.pdf [Accessed: 26, June 2013].

Detragiache, E., Gupta, P., 2006. Foreign banks in emerging market crises: evidence from Malaysia. J. Financ. Stab. 2 (3), $217-242$.

Farazi, S., Feyen, E., Rocha, R., 2011. Banks Ownership and Performance the Middle East and North African Region. World Bankpp. 7-21. Available through: http:// elibrary.worldbank.org/content/workingpaper/10.1596/1813-9450-5620 [Accessed: 02, July 2013].

Focarelli, D., Pozzolo, A., 2000. The Determinants of Cross-Border Bank Share Holdings: An Analysis with Bank-Level Data from OECD Countries. Bank of Italy, Research departmentpp. 9-32. http://www.bancaditalia.it/pubblicazioni/econo/temidi/td00/td381_00/td381/tema_381_00.pdf [Accessed: 02, March 2013].

Fries, S., Taci, A., 2005. Cost efficiency of banks in transition: evidence from 289 banks in 15 post-communist countries. J. Bank. Finance 29 (1), 55-89.

Grosse, R., Goldberg, L., 1991. Foreign bank activity in the United States: an analysis by country of origin. J. Bank. Finance 15 (6), $1093-1112$.

Hassan, M., Sanchez, B., Ngene, G.M., Ashraf, A., 2012. Financial liberalization and foreign bank entry on the domestic banking performance in MENA countries. Afr. Dev. Rev. 24 (3), 195-207.

Heggestad, A., 1997. Market structure, risk and profitability in commercial banking. J. Finance 32 (4), $1207-1216$.

Hryckiewicz, A., Kowalewski, O., 2010. Economic determinates, financial crisis and entry modes of foreign banks into emerging markets. Emerg. Mark. Rev. 11 (3), 205-228.

Jeon, Y., Miller, S.M., 2005. Performance of domestic and foreign banks: the case of Korea and Asian crisis. Global Econ. Rev. 34 (2), $145-165$.

Jeon, B., Olivera, M., Wu, J., 2011. Do foreign banks increase competition? Evidence from emerging Asian and Latin American banking markets. J. Bank. Finance 35 (4), 856-875.

Kosmidou, K., Pasiouras, F., Tzanetoulakos, A., 2007. Domestic and multinational determinants of foreign bank profits: the case of Greek banks operating abroad. J. Multinat. Financ. Manag. 17 (1), 1-15.

La Porta, R., Lopez-De-Silanes, F., Shleifer, A., 2002. Government ownership of banks. J. Finance 57 (1), $265-301$.

Lassoueda, N., Sassib, H., Attia, M.B.R., 2016. The impact of state and foreign ownership on banking risk:evidence from the MENA countries. Res. Int. Bus. Finance 36, $167-178$.

Lee, J., 2002. Financial Liberalization and Foreign Bank Entry in MENA1. World Bankpp. 2-28. Available through: World Bank http://info.worldbank.org/etools/ docs/library/154927/financeforum2002/pdf/lee_mena.pdf [Accessed: 27 April 2013].

Micco, A., Panizza, U., Yañez, M., 2007. Bank ownership and performance. Does politics matter? J. Bank. Finance 31 (1), $219-241$.

Nandy, M., Lodh, S., 2012. Do banks value the eco-friendliness of firms in their corporate lending decision? Some empirical evidence. Int. Rev. Financ. Anal. 25, 83-93. Olson, D., Zoubi, T.A., 2011. Efficiency and bank profitability in MENA countries. Emerg. Mark. Rev. 12 (2), 94-110.

Omran, M., 2007. Privatization, state ownership, and bank performance in Egypt. World Dev. 35 (4), 714-718.

Parashar, S., Venkatesh, J., 2010. How did Islamic banks do during global financial crisis? Banks Bank Syst. 5 (4), 54-60.

Schnitzer, M., 2013. Enterprise restructuring and bank competition in transition economies. Econ. Trans. 7 (1), $133-137$.

Staikouras, C., Mamatzakis, E., Koutsomanoli-Filippak, A., 2008. Cost efficiency of the banking industry in the South Eastern European region. J. Int. Financ. Mark. Inst. Money 18 (5), 483-497.

Sturm, J., Williams, B., 2004. Foreign bank entry, deregulation and bank efficiency: lessons from the Australian experience. J. Bank. Finance 28 (7), 1775-1799.

Valverde, S., Fernández, F., 2007. The determinants of bank margins in European banking. J. Bank. Finance 31 (7), $2043-2050$.

Van Horen, N., 2007. Foreign banking in developing countries; origin matters. Emerg. Mark. Rev. 8 (2), $81-105$.

Van Tassel, E., Vishwasrao, S., 2007. Asymmetric information and the mode of entry in foreign credit markets. Bank. Finance 31 (12), 3742-3760. 